\title{
Testday models for production traits in dairy cattle
}

\author{
B.E. Mostert ${ }^{1 \#}$, E. Groeneveld ${ }^{2}$ and F.H.J. Kanfer ${ }^{3}$ \\ ${ }^{1}$ ARC-AII, Private Bag X2, Irene, 0062, South Africa. \\ ${ }^{2}$ Institute for Animal Husbandry and Animal Behaviour, FAL, Mariensee, 31535 Neustadt, Germany \\ ${ }^{3}$ Department of Statistics, University of Pretoria, Pretoria, 0002, South Africa.
}

\begin{abstract}
Methodology has been developed to implement testday models in the national genetic evaluation of dairy breeds for production traits in South Africa. Positive definite covariance matrices have been estimated, using multitrait, multi-lactation, fixed regression testday BLUP animal models, including testday records of the first three lactations as repeated measures for the Holstein and Jersey breeds. Heritability estimates were $0.40 \pm 0.007$ for milk yield, $0.25 \pm 0.006$ for butterfat yield and $0.37 \pm 0.006$ for protein yield for the Holstein breed and $0.39 \pm 0.004$ for milk yield, $0.21 \pm 0.002$ for butterfat yield and $0.34 \pm 0.002$ for protein yield for the Jersey breed. These estimates are well in the range of estimates reported by countries participating in INTERBULL evaluations.
\end{abstract}

Keywords: Fixed regression, Holstein, Jersey, testday, Wilmink curve

\#Corresponding author. E-mail: bernice@irene.agric.za

\section{Introduction}

Dairy sires in South Africa were first genetically evaluated through progeny groups, using data recorded by the National Livestock Improvement Scheme. This led to the utilization of contemporary comparison methods to estimate the breeding values of sires. Dairy animals received breeding values from BLUP (Best Linear Unbiased Prediction) Methodology for the first time in 1987, when breeding values were estimated, using a Sire Model. In 1992 the Animal Model was fitted to dairy records to estimate breeding values in single trait analyses. Since 1999 multitrait analyses were developed for the South African dairy breeds, where 305-day milk, butterfat and protein first lactation yields were evaluated together in order to utilize the genetic correlations between the traits to estimate breeding values even more accurately (Loubser et al., 2001). Genetic groups were also incorporated into the pedigrees in order to qualify in 2000 for participation in INTERBULL runs for the estimation of MACE (Multiple Across Country Evaluation) breeding values. Using only completed first lactation records in genetic analyses have of course several disadvantages. A cow that did not participate in milk recording during her first lactation or for some reason her first lactation was terminated before 240 days in milk, never receive a breeding value based on performance, regardless of her performance in later lactations. Furthermore, the performance of the cows in second and third lactations is never included, rendering less accurate genetic evaluations especially for "late bloomers". The basis of a 305-day yield is a set of testday yields taken approximately every 30 days in milk. Incomplete lactations are extended to a 305-day basis following a set of well-defined rules (Ptak \& Schaeffer, 1993). Such projection procedures usually assume a fixed shape of lactation curves for cows and tend to underestimate 305-day yields from early testdays for more persistent cows and overestimate yields for the less persistent cows (Mrode et al., 2002). One way to avoid the problem of extension of testday yields into a 305-day record would be to use testday yields for genetic evaluation of dairy sires and cows, rather than 305-day yields. The aim of this study was therefore to develop a genetic model and to estimate covariance matrices that could be used to evaluate sires and cows in South Africa, based on testday yields from lactations 1 to 3 .

\section{Materials and Methods}

Data consisted of testday records for milk, butterfat and protein yields for lactations 1, 2 and 3 of Holstein and Jersey cows calving from 1995 to 2002. These records were downloaded from the INTERGIS for cows participating in the South African Dairy Animal Improvement Scheme. Basic edits were done on the data and in order to ensure a well-linked data structure for variance component estimation, the data were strictly selected according to the study of Haile-Mariam et al. (2000). After research was done on the estimation of breeding values for somatic cell count using testday models in South Africa (Mostert et al., 2004), it was decided to include records from the first three lactations as repeated measures of the first lactation, assuming a genetic correlation of 1 across lactations. By using this methodology, it was still 
possible in terms of computer capacity and time, to do multitrait analyses for production traits. Starting with the Holstein data a subset of 34662 testday records were used from the abovementioned selection for variance component estimation. This included 10955 testday records for lactation 1, 14955 records for lactation 2 and 8752 for lactation 3. This is the data of 3093 cows, representing 250 sires and 3052 dams. For the Jerseys the selection ended with 88572 testday records for the first lactation, 70009 records in the second lactation and 30870 records in the third lactation, representing 17758 cows, 473 sires and 14941 dams. (Co)variance components were estimated using VCE4 (Groeneveld \& Garcia-Cortes, 1998) with the following genetic model:

\begin{tabular}{|c|c|c|}
\hline Where & & $D L M_{i m}+A_{j}+P E_{j m}+S_{k m}+A C_{l m}+w 1 l m i n k\left(S_{k m}\right)+C I_{j m}+$ eljklmnp \\
\hline$y_{i j k l m n p}$ & $=$ & $\mathrm{p}^{\text {th }}$ test-day milk, butterfat or protein yield of cow $\mathrm{j}$ in lactation $\mathrm{m}$, \\
\hline${ }_{H T D L}^{\mu} M_{i m}$ & $=$ & fixed effect of herd $\mathrm{x}$ testdate $\mathrm{x}$ parity $\mathrm{x}$ number of milkings effect \\
\hline & $=$ & animal additive genetic effect \\
\hline$P E_{j m}$ & $=$ & $\begin{array}{l}\text { permanent environmental (random) effect within lactation to account for } \\
\text { common effects of environment associated with all testday records of cow } j \\
\text { in lactation m }\end{array}$ \\
\hline$S_{k m}$ & $=$ & fixed effect of calving season in lactation $\mathrm{m}$ \\
\hline $\mathrm{AC}_{\operatorname{lm}}$ & $=$ & fixed effect of ageclass in lactation $\mathrm{m}$ \\
\hline $\operatorname{wilmink}\left(S_{k m}\right)$ & $=$ & $\begin{array}{l}\text { Wilmink curve (Wilmink, 1987) modelled on days in milk within season in } \\
\text { lactation m (regression) }\end{array}$ \\
\hline $\mathrm{CI}_{\mathrm{n} m}$ & $=$ & fixed effect of calving interval class in lactation m \\
\hline$e_{i j k l m n}$ & $=$ & random residual error \\
\hline
\end{tabular}

Season was defined as winter (April - September) versus summer (October - March), while the same ageclasses were allocated as in the derivation of standard lactation curves by Mostert et al. (2001). Calving interval classes were allocated using standard deviation units. A series of univariate and bivariate analyses were run as well as a trivariate analysis for each breed. Heritabilities and genetic correlations from the trivariate analyses are indicated in Table 2.

\section{Results and Discussion}

The advantages of a testday model include a more accurate correction for environmental effects relevant to each testday record (Ptak \& Schaeffer, 1993); the ability to model the shape of the lactation curve to differ for each cow, estimation of persistency evaluations (Jamrozik et al., 1997), as well as the use of early predictors of genetic merit for selection decisions, thereby decreasing the generation interval. Other advantages are that records do not need to be extended, erasing debates over extension factors; better modelling of the effect of pregnancy can occur because a testday can directly be linked to whether or not a cow is pregnant and that further subdivision of the contemporary group into management groups is feasible if they are recorded (Swalve, 2000). Testday models, however, are computationally very demanding. For evaluations on a national scale, the size of the equation system can go to hundreds of millions of equations, depending on the size of the database and the specific model defined. Furthermore, all the individual testday yields on every cow need to be stored. All analyses converged with status 1, giving positive definite matrices. Heritabilities were slightly higher for the Holstein breed for all traits, while the genetic correlation between milk and butterfat yields was similar (0.84) and between milk and protein yields was slightly higher for the Holstein breed (0.94 vs. 0.92) compared to the Jersey breed. Only the genetic correlation between butterfat and protein yields was higher for the Jersey breed compared to the Holstein breed (0.91 vs. 0.88). As can be expected, the genetic correlations between the permanent environmental effects were high for both breeds, while the direct estimates for permanent environment for the Holstein breed were nearly half of that of the Jerseys for all traits. Residual estimates (direct and correlations) were higher for the Holsteins compared to the Jerseys for all traits. Both breeds showed the same pattern regarding residual correlations, namely correlations in the sixties between milk and butterfat yields and between butterfat and protein yields, whereas the correlations between milk and protein yields were in the nineties for both breeds.

These estimates are within the range of estimates reported by countries participating in INTERBULL evaluations (obtainable at www-interbull.slu.se) (Table 2). 
Peer-reviewed paper: Joint South African Society for Animal Science/Grassland Society of Southern Africa Congress

Table 1 Variance ratios (on the diagonal) and correlations (above the diagonal) for milk, butterfat and protein yield (kg/day) of Jersey and Holstein cattle, using fixed regression testday models

\begin{tabular}{|c|c|c|c|c|c|c|}
\hline & \multicolumn{3}{|c|}{ Holstein } & \multicolumn{3}{|c|}{ Jersey } \\
\hline Additive & Milk & Butterfat & Protein & Milk & Butterfat & Protein \\
\hline Milk & $0.40 \pm 0.007$ & $0.84 \pm 0.006$ & $0.94 \pm 0.002$ & $0.39 \pm 0.004$ & $0.84 \pm 0.002$ & $0.92 \pm 0.001$ \\
\hline Butterfat & & $0.25 \pm 0.006$ & $0.88 \pm 0.005$ & & $0.21 \pm 0.002$ & $0.91 \pm 0.002$ \\
\hline Protein & & & $0.37 \pm 0.006$ & & & $0.34 \pm 0.002$ \\
\hline Perm Env & Milk & Butterfat & Protein & Milk & Butterfat & Protein \\
\hline Milk & $0.13 \pm 0.008$ & $0.98 \pm 0.005$ & $0.99 \pm 0.002$ & $0.23 \pm 0.003$ & $0.96 \pm 0.002$ & $0.98 \pm 0.001$ \\
\hline Butterfat & & $0.09 \pm 0.006$ & $0.99 \pm 0.004$ & & $0.16 \pm 0.002$ & $0.96 \pm 0.002$ \\
\hline Protein & & & $0.11 \pm$ & & & $0.20 \pm 0.002$ \\
\hline Residual & Milk & Butterfat & Protein & Milk & Butterfat & Protein \\
\hline Milk & $0.47 \pm 0.006$ & $0.67 \pm 0.002$ & $0.93 \pm 0.001$ & $0.39 \pm 0.002$ & $0.64 \pm 0.001$ & $0.91 \pm 0.00$ \\
\hline Butterfat & & $0.67 \pm 0.007$ & $0.66 \pm 0.003$ & & $0.63 \pm 0.002$ & $0.62 \pm 0.001$ \\
\hline Protein & & & $0.53 \pm 0.007$ & & & $0.46 \pm 0.002$ \\
\hline
\end{tabular}

Table 2 Heritability estimates for Holsteins reported by countries participating in INTERBULL evaluations

\begin{tabular}{llccc}
\hline Country & \multicolumn{1}{c}{ Model } & Milk & Butterfat & Protein \\
\hline Canada & MT-ML-RR-TD & $0.36-0.39$ & $0.33-0.37$ & $0.35-0.37$ \\
Estonia & ST-ML-FR-TD & 0.27 & 0.23 & 0.24 \\
Germany & ST-ML-RR-TD & 0.49 & 0.48 & 0.48 \\
NLD/BEL & ST-ML-RR-TD & 0.59 & 0.58 & 0.52 \\
Switzerland & ST-ML-FR-TD & 0.36 & 0.30 & 0.32 \\
\hline MT=Multitriat ML=Multi-lactation RR=Random Regression TD=Testday ST=Single trait FR=Fixed Regression
\end{tabular}

MT=Multitriat ML=Multi-lactation RR=Random Regression TD=Testday ST=Single trait FR=Fixed Regression

\section{Conclusion}

Methodology has been developed to implement testday models in the national genetic evaluation of dairy breeds for production traits in South Africa. Positive definite covariance matrices have been estimated, using multitrait, multi-lactation, fixed regression testday BLUP animal models, including testday records of the first three lactations as repeated measures for the Holstein and Jersey breeds. These methods will be implemented after participation in the test runs of INTERBULL in Sweden during March and September 2004.

\section{References}

Groeneveld, E. \& Garcia-Cortes, A., 1998. VCE4.0, a (co)variance component package for frequentists and bayesians. Proc. $6^{\text {th }}$ World Cong. Gen. Appl. Livest. Prod. 27, 455-456.

Haile-Mariam, M., Goddard, M.E. \& Bowman, P.J., 2000. Estimates of genetic parameters for daily somatic cell count of Australian dairy cattle. J. Dairy Sci. 84, 1255-1264.

Jamrozik, J., Dekkers, J.C.M. \& Schaeffer, L.R., 1997. Genetic evaluation of dairy cattle using testday yields and random regression models. J. Dairy Sci. 80, 1217-1226.

Loubser, L.F.B., Banga, C.B., Scholtz, M.M. \& Hallowell, G.J. (Eds.), 2001. Dairy herd improvement in South Africa. The use of breeding values in the South African Dairy Industry. 25. ARC-AII.

Mostert, B.E., Theron, H.E. \& Kanfer, F.H.J., 2001. The effect of calving season and age at calving on production traits of South African dairy cattle. S. Afr. J. Anim. Sci. 31, 205-210.

Mostert, B.E., Banga, C., Groeneveld, E. \& Kanfer, F.H.J., 2004. Breeding value estimation for somatic cell score in South African dairy cattle. S. Afr. J. Anim. Sci. 34 (supplement 2), 32-34.

Mrode, R.A., Swanson, G.J.T. \& Lindberg, C.M., 2002. Efficiency of part lactation testday records for genetic evaluations using fixed and random regression models. Anim. Sci. 74, 189-197.

Ptak, E. \& Schaeffer, L.R., 1993. Use of testday yields for genetic evaluation of dairy sires and cows. Livest. Prod. Sci. 34, 23-34.

Swalve, H.H., 2000. Symposium: Test-Day Models. Theoretical basis and computational methods for different test-day genetic evaluation methods. J. Dairy Sci. 83, 1115-1124.

Wilmink, J.B.M., 1987. Adjustment of test-day milk, fat and protein yield for age season and stage of lactation. Livest. Prod. Sci. 16, 335-348. 